\title{
Point of View \\ Nitric oxide in plants: a brief discussion on this multifunctional molecule
}

\author{
Leonardo Cesar Ferreira $^{1 *}$; Ana Catarina Cataneo ${ }^{2}$ \\ ${ }^{1}$ UNESP/IB - Depto. de Botânica, C.P. 510 - $18618-000$ - Botucatu, SP - Brasil. \\ ${ }^{2} U N E S P / I B$ - Depto. de Química e Bioquímica. C.P. 510 - 18618-000 - Botucatu, SP - Brasil. \\ *Corresponding author<pgleo_ferreira@yahoo.com.br>
}

\begin{abstract}
Several studies were carried out in order to improve the knowledge about the occurrence and activity of nitric oxide $(\mathrm{NO})$ in plants. Thus, this review discusses some aspects related to $\mathrm{NO}$ in plants such as chemical properties, synthesis pathways, physiological effects, antioxidant action, signal transduction, interaction with plant hormones and gene expression. In the last years, many advances have been obtained regarding NO synthesis and its physiological effects in plants. However, the molecular mechanisms underlying its effects remain poorly understood. It is signalized that tight interplays among $\mathrm{NO}, \mathrm{Ca}^{2+}$, cyclic $\mathrm{ADP}$ ribose (cADPR), and protein kinases need to be investigated in details. In addition, it has not yet been possible to identify a plant enzyme displaying a nitric oxide synthase (NOS)-like activity. The elucidation of such aspects represents a challenge to future studies.
\end{abstract}

Key words: pathogenesis, plant hormones, plant signal transduction, reactive oxygen species

\section{Óxido nítrico em plantas: breve abordagem sobre essa molécula multifuncional}

\begin{abstract}
RESUMO: Diversos estudos vêm sendo realizados com a finalidade de aumentar o conhecimento sobre a ocorrência e a atividade do óxido nítrico $(\mathrm{ON})$ nas plantas. Nesse sentido, a presente revisão objetivou abordar alguns aspectos referentes ao $\mathrm{ON}$ nas plantas, tais como propriedades químicas, vias de síntese, efeitos fisiológicos, ação antioxidante, transdução do sinal, interação com hormônios vegetais e expressão gênica. Nos últimos anos, muitos avanços têm sido obtidos em relação à síntese de $\mathrm{ON}$ e seus efeitos fisiológicos nas plantas. Porém, os mecanismos moleculares que fundamentam seus efeitos permanecem pouco compreendidos. É sinalizada uma investigação em detalhes sobre as estreitas interações entre $\mathrm{ON}, \mathrm{Ca}^{2+}, \mathrm{ADP}$-ribose cíclica (cADPR) e proteínas quinases. Além disso, ainda não foi possível identificar uma enzima vegetal que apresente atividade semelhante à da óxido nítrico sintase (NOS). A elucidação de tais aspectos representa um desafio para futuros trabalhos.

Palavras-chave: patogênese, hormônios vegetais, transdução do sinal nas plantas, espécies reativas do metabolismo do oxigênio
\end{abstract}

\section{Introduction}

Formerly, the plant hormone ethylene was the only gaseous signaling molecule in the living world known to science. However, nitric oxide (NO) was established in the 1998 Nobel Prize for Medicine as another player of this kind in mammalian cells (Wojtaszek, 2000). NO has been initially identified as an endothelium-derived relaxation factor, and later implicated in signal transduction pathways controlling neurotransmission, cell proliferation, programmed cell death, and host responses to infection (Wink and Mitchell, 1998). Although the history of studies on NO in animals is considerably much more advanced, renewed attention has been given to the mechanism of NO synthesis and its functions in plants in the last decades. NO emission from plants was first observed by Klepper in 1975, much earlier than in animals, in soybean (Glycine max L. Merril) plants treated with herbicides (Klepper, 1979).
Yamasaki (2005) stated that plant systems are more open to the environment and to NO than are those of vertebrates. Thus, Arasimowicz and Floryszak-Wieczorek (2007) highlighted that plant NO signalling network should be more sensitive to exogenous NO emission, e.g. soil bacteria (nitrification/denitrification), soil fertilization or air pollutants, than closed animal systems localized in specific tissues. As regards the physiological functions of $\mathrm{NO}$ in plants, several works reported its involvement in the inhibition of foliage expansion (Beligni and Lamattina, 1999c), cell wall lignification (Ferrer and Ros Barcelo, 1999), root organogenesis (Pagnussat et al., 2002), sexual reproduction (Grün et al., 2006), germination (Beligni and Lamattina, 2000; Neill et al., 2003; Zanardo et al., 2005), and seed dormancy breaking (Bethke et al., 2006).

The present review aimed to discuss some aspects on NO action in plants, such as chemical properties, synthesis pathways, antioxidant action, signal transduction, interaction with plant hormones, and gene expression. 


\section{Chemical properties of $\mathrm{NO}$}

$\mathrm{NO}$ is one of the smallest diatomic molecules with a high diffusivity $\left(4.8 \times 10^{-5} \mathrm{~cm}^{2} \mathrm{~s}^{-1}\right.$ in $\left.\mathrm{H}_{2} \mathrm{O}\right)$, exhibiting hydrophobic properties. Thus, NO may not only easily migrate in the hydrophilic regions of the cell, such as the cytoplasm, but also freely diffuse through the lipid phase of membranes (Arasimowicz and FloryszakWieczorek, 2007). The half-life of NO in biological tissues is estimated to be $<6 \mathrm{~s}$ (Bethke et al., 2004). This short half-life reflects the highly reactive nature of NO, which reacts directly with metal complexes and other radicals and indirectly as a reactive nitrogen oxide species with DNA, proteins, and lipids (Wink and Mitchell, 1998).

\section{NO synthesis}

There are many possible sources of NO (Figure 1). Although in animals NO is generated almost exclusively by nitric oxide synthase (NOS, EC 1.14.13.39), in bacteria, fungi, and plants the presence of NO is intimately implicated in their metabolism, and in fact is one of the elements of nitrogen cycling on Earth (Wojtaszek, 2000). Nitrification/denitrification cycles provide $\mathrm{NO}$ as a byproduct of $\mathrm{N}_{2} \mathrm{O}$ oxidation into the atmosphere (Durner and Klessig, 1999). Plants not only react to the atmospheric or soil NO, but are also able to emit substantial amounts of NO. Thus, NO could be generated by nonenzymatic mechanisms, e.g. via chemical reduction of $\mathrm{NO}_{2}^{-}$at acidic $\mathrm{pH}$ or by carotenoids in the presence of light (Cooney et al., 1994) and at acidic $\mathrm{pH}$ in the presence of a reductant such as ascorbic acid (Crawford, 2006).

The major origin of NO production in plants however is probably through the action of NAD $(\mathrm{P}) \mathrm{H}$-dependent nitrate (NR, EC 1.6.6.1) or nitrite (NiR, EC 1.7.7.1) reductases (Yamasaki et al., 1999). NR provided the first known mechanism to make NO in plants. This enzyme normally reduces nitrate to nitrite, but it can also further reduce nitrite to NO (Crawford, 2006). NR is the only enzyme whose NO-producing activity has been rigorously confirmed both in vivo and in vitro (Courtois et al., 2008).
Chandok et al. (2003) identified in tobacco another candidate for NO enzymatic production in plants - the inducible NO synthase (iNOS), which is induced by pathogens and was identified as a variant of the $\mathrm{P}$ protein of the mitochondrial glycine decarboxylase complex. In addition, Godber et al. (2000) suggested that xanthine oxidase, a ubiquitous molybdo-enzyme, could catalyse the reduction of nitrite to NO under hypoxia and in the presence of NADH. Stöhr et al. (2001) reported a tobacco root-specific plasma membrane-bound nitrite:NO reductase (NI-NOR), which catalyzes the reduction of apoplastic nitrite into NO. Later, Stöhr and Stremlau (2006) reported that NI-NOR may be involved in several physiological root processes, including development, response to anoxia, and symbiosis. Also, Besson-Bard et al. (2008a) stated that NI-NOR activity might be coordinated with those of a plasma membranebound NR (PM-NR) reducing apoplastic nitrate to nitrite. However, the identity of NI-NOR is currently unknown.

Analogous to that used by animal NOS, an argininedependent mechanism has emerged from plants as regards NO synthesis, which suggests that plants have orthologues to animal NOS enzymes (Crawford, 2006). Ribeiro Jr. et al. (1999) reported that anti-mammalian NOS antibodies cross-react with plant proteins. However, Butt et al. (2003) observed that such proteins are not related to NOS and include such proteins as heat shock proteins and glycolytic enzymes.

NOS functional activities have been detected in plant tissue extracts and purified organelles, including peroxisomes and mitochondria (Besson-Bard et al., 2008a). However, there is no direct experimental evidence that the radioactive products detected when assessing plant NOS activity in vitro is indeed L-citrulline (Crawford et al., (2006). Also, no protein or gene was identified that had any sequence similarity to the complete animal NOS proteins (Crawford, 2006). A gene in Arabidopsis (At3g47450) encodes a protein (AtNOS1) that is 16\% identical to the snail protein (Guo et al., 2003a). Thus, a T-DNA insertion mutant was obtained from the Arabidopsis Biological Resource Center (The Ohio State

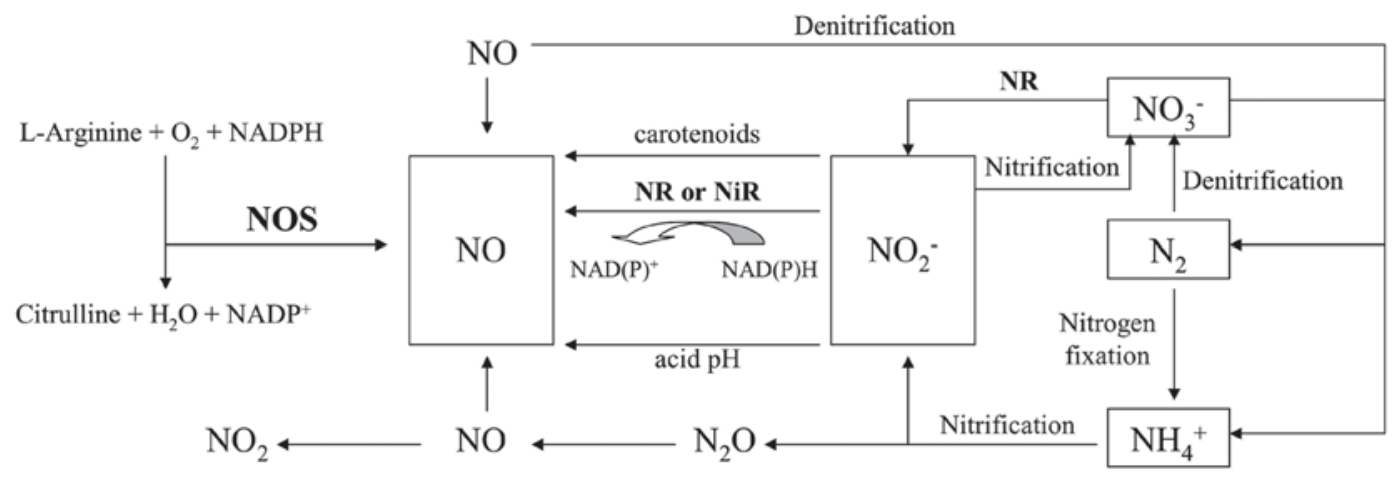

Figure 1 - Possible sources of NO. NO: nitric oxide; $\mathrm{N}_{2} \mathrm{O}$ : nitrous oxide; $\mathrm{NO}_{3}^{-}$: nitrate; $\mathrm{NO}_{2}^{--}$: nitrogen dioxide; $\mathrm{NH}_{4}^{+}$: ammonium; NR: nitrate reductase; NiR: nitrite reductase; NOS: nitric oxide synthase. Adapted from Wojtaszek (2000). 
University, Rightmire Hall, 1060 Carmack Road, Columbus, $\mathrm{OH} 43210$, USA) in order to investigate if the Arabidopsis protein had anything to do with NO synthesis in plants (Alonso et al., 2003). The characterization of this mutant led to an initial finding that showed this protein as being a central player in NO synthesis in Arabidopsis, since NO levels were found to be lower in the Atnos1 mutants impaired in AtNOS1 expression (Guo et al., 2003a). However, Crawford (2006) suggested that other genes are involved in the NO synthesis.

The involvement of polyamines (PAs) in the $\mathrm{NO}$ synthesis is another important aspect to be considered (Besson-Bard et al., 2008a). Tun et al. (2006) added the polyamines spermidine and spermine to Arabidopsis seedlings and observed rapid production of $\mathrm{NO}$ in the elongation zone of the root tip and in primary leaves, especially in the veins and trichomes. Yamasaki and Cohen (2006) stated that the PA-dependent NO production might be carried out by unknown enzymes or by PA oxidases.

\section{$\mathrm{NO}$ acts as an antioxidant against ROS}

A great variety of abiotic stresses including drought, salinity, ultraviolet light, air pollutants and heavy metals cause molecular damage to plants, either directly or indirectly through reactive oxygen species (ROS) formation (Laspina et al., 2005), such as superoxide $\left(\mathrm{O}_{2}^{-*}\right)$ and hydroxyl $\left(\mathrm{OH}^{*}\right)$ radicals, hydrogen peroxide $\left(\mathrm{H}_{2} \mathrm{O}_{2}\right)$, and oxygen singlet $\left({ }^{1} \mathrm{O}_{2}\right)$ (Thérond et al., 2000). Whereas some authors considered NO as a stress-inducing agent (Leshem, 1996), others have reported its protective role (Beligni and Lamattina, 1999a, b; Hsu and Kao, 2004), depending on its concentration, the plant tissue or age, and the type of stress. Literature data supply evidence showing that plant response to such stressors as drought (Garcia-Mata and Lamattina, 2001; Neill et al., 2002), salinity (Zhao et al., 2004, 2007) and cadmium (Hsu and Kao, 2004; Kopyra and Gwózdz, 2003), is regulated by NO.

$\mathrm{NO}$ is a highly reactive molecule and the fact of being a free radical allows it to scavenge other reactive intermediates and end chain-propagated reactions (Kopyra and Gwózdz, 2003). Thus, two mechanisms by which NO might abate stress have been postulated. First, NO might function as an antioxidant by directly scavenging ROS, such as $\mathrm{O}_{2}^{*}$, to form peroxynitrite (ONOO) (Laspina et al., 2005). Second, NO could function as a signalling molecule in the cascade of events leading to changes of gene expression (Lamattina et al., 2003; Laspina et al., 2005). The rapid reaction between $\mathrm{O}_{2} *$ and $\mathrm{NO}$ to form the powerful oxidant peroxynitrite (ONOO) has been suggested as a deleterious mechanism (Leshem, 2000), because ONOO oxidizes DNA, lipids, protein thiols and iron clusters, resulting in impaired enzyme activities and cellular damage (Beligni and Lamattina, 1999a; Van Breusegem et al., 2001). However, in systems where the toxicity comes predominantly from peroxides, these compounds are much more toxic than $\mathrm{NO}$ and $\mathrm{ONOO}$, making $\mathrm{NO}$ protective against them (Wink et al., 1993). Thus, interaction of NO with lipid alcoxyl or lipid peroxyl radicals breaks the selfperpetuating chain reaction during lipid peroxidation (Beligni and Lamattina, 1999a; Van Breusegem et al., 2001).

NO counteracts the toxicity of ROS generated by diquat or paraquat in potato (Solanum tuberosum ssp tuberosum L.) and rice (Oryza sativa L.) (Beligni and Lamattina, 1999c; Hung et al., 2002). Orozco-Cárdenas and Ryan (2002) demonstrated that $\mathrm{NO}$ blocks $\mathrm{H}_{2} \mathrm{O}_{2}$ production induced by jasmonic acid in tomato (Lycopersicon esculentum Mill.) leaves. Furthermore, Sun et al. (2007) reported that NO can protect maize (Zea mays L.) plants from iron deficiency-induced oxidative stress by reacting with ROS directly or by changing activities of ROS-scavenging enzymes.

\section{$\mathrm{NO}$ acts in plant signal transduction}

NO can react rapidly with thiol- and transition metal-containing proteins, including a wide functional spectrum of proteins such as receptors, transcription factors and cellular messengers (Stamler et al., 2001). According to Besson-Bard et al. (2008b), more than 100 proteins have been identified as targets for $\mathrm{NO}$ in vitro and/ or in vivo. Hemoglobin, lipoxygenase, cytosolic and mitochondrial aconitases, catalase, ascorbate peroxidases, and cytochrome $\mathrm{c}$ oxidase are putative targets of $\mathrm{NO}$, regulated via metal nitrosylation in biological systems. Durner et al. (1998) studied guanylate cyclase and the resulting activation of cyclic GMP (cGMP)-dependent signalling pathway. This relation was demonstrated in tobacco mosaic virus (TMV)-infected tobacco (Nicotiana tabacum L.) and an involvement of another NO-dependent signalling molecule: cyclic ADP-ribose (cADPR) was also detected. Besides, the effect of NO-releasing compounds on phytochrome-controlled germination of empress tree seeds (Paulownia tomentosa) has been attributed to NO-dependent cGMP production (Giba et al., 1998).

The covalent attachment of a nitrogen monoxide group to the thiol side chain of cysteine - S-nitrosylation - has been considered the most widespread and functionally important form of physiological NO-dependent posttranslational modification (Hess et al., 2005). Such reaction is not enzymatically catalysed and depends on the local concentrations of NO, which is controlled by NO synthesis and scavenging rates (Crawford, 2006). Glyceraldehyde 3-phosphate dehydrogenase, methionine adenosyltransferase and nonsymbiotic hemoglobin are S-nitrosylated proteins experimentally identified (Belenghi et al., 2007).

The involvement of protein Tyr nitration in plants has been reported regarding NO signalling. MorotGaudry-Talarmain et al. (2002) have demonstrated increased protein Tyr nitration in an antisense nitrite reductase tobacco line that displays a 100 -fold higher NRmediated NO emission rate compared with the wildtype. Furthermore, Saito et al. (2006) observed protein Tyr nitration in tobacco cells treated with INF1, 
an elicitor secreted by Phytophthora infestans that promotes defense responses. In addition, Valderrama et al. (2007) detected protein Tyr nitration in olive leaves exposed to salt stress. NO contributes to in an increased level of cytosolic calcium $\left(\mathrm{Ca}^{2+}\right)$ in tobacco cells as a consequence of applied hyperosmotic stress and treatment with a fungal elicitor - cryptogein (Lamotte et al., 2004). Similarly, the participation of NO in abscisic acid (ABA)-induced stomatal closure in guard cells was found to be correlated with an increase of cytosolic $\mathrm{Ca}^{2+}$ concentration (Garcia-Mata and Lamattina, 2003).

Strong evidence that $\mathrm{NO}$ regulates cytosolic $\mathrm{Ca}^{2+}$ homeostasis in plant cells was provided by Lamotte et al. (2006). Such authors used tobacco cells expressing $\mathrm{Ca}^{2+}$ reporter apoaequorin subjected to hyperosmotic stress and showed that $\mathrm{NO}$ emitted from the NO donor was able to activate both plasma membrane and intracellular $\mathrm{Ca}^{2+}$-permeable channels via signalling cascades involving plasma membrane depolarization, cADPR, and protein kinases. The same authors first characterized the NO target which appeared to be a $42-\mathrm{kDa}$ protein kinase named Nicotiana tabacum Osmotic-StressActivated protein Kinase (NtOSAK) - a member of the plant Sucrose Non Fermenting (SNF) 1-related protein kinase type 2 (SnRK2) family. NtOSAK activity might be up-regulated through phosphorylation by an upstream NO-dependent protein kinase, by auto-phosphorylation, and/or through direct S-nitrosylation or nitration by NO-derived species, although preliminary experiments are not in favor of the last possibility (Courtois et al., 2008).

In addition to NtOSAK, $\mathrm{NO}$ induced the activation of a second protein kinase with a molecular mass of 48 $\mathrm{kDa}$, which is likely to be a Mitogen-Activated Protein Kinase (MAPK). Salicylic acid-Induced Protein Kinase (SIPK) is a tobacco $48-\mathrm{kDa}$ MAPK that is activated in response to pathogens and osmotic stress. Then, the NOinduced $48-\mathrm{kDa}$ MAPK was immunoprecipitated by the anti-SIPK antibodies, thus demonstrating that it is SIPK. The activation of SIPK could be preceded by a rise in $\left[\mathrm{Ca}^{2+}\right]_{\mathrm{cyt}}$ triggered by the NO-dependent activation of plasma membrane $\mathrm{Ca}^{2+}$-permeable channels (BessonBard et al., 2008a). According to the same authors, NO might promote an influx of $\mathrm{Ca}^{2+}$ from the extracellular space and/or mobilization of $\mathrm{Ca}^{2+}$ sequestered in intracellular $\mathrm{Ca}^{2+}$ stores, depending on the physiological context. Besides, ryanodine receptors (RYR)-like channels have been considered the main targets for $\mathrm{NO}$, although the identity of the $\mathrm{Ca}^{2+}$-permeable channels involved in that process remains unknown. Fliegert et al. (2007) suggested that cADPR mediates $\mathrm{Ca}^{2+}$ release by activating the intracellular $\mathrm{Ca}^{2+}$ channels RYR in mammals but also in plants. In addition, Ali et al. (2007) identified CNGC2, a plasma membrane Arabidopsis cyclic nucleotide-gated channel (CNGC) member, as a key $\mathrm{Ca}^{2+}$-permeable channel that links elicitor-induced $\mathrm{Ca}^{2+}$ influx to downstream NOS-like mediated NO production. Also, the possibility should be mentioned that NO might influence the activity of inositol 1,4,5-triphosphate receptors (Vandelle et al., 2006).

It is apparent that ROS and NO are acting as key signal molecules in plants (Herouart et al., 2002). This was first described in pathogenesis, where the initial defense response is often manifested as the so-called hypersensitive response (HR). One of the earliest events in the HR is the rapid accumulation of ROS - the socalled oxidative burst - and NO (Van Camp et al., 1998). These activated species are involved in the regulation of gene expression during the HR and they appear to play a key role in the coordination of the plant responses to pathogen challenge (Herouart et al., 2002).

Manjunatha et al. (2008) evaluated NO donors for their effectiveness in protecting pearl millet [(Pennisetum glaucum L.) R. Br.] plants against downy mildew disease caused by Sclerospora graminicola [(Sacc). Schroet]. Expression of primary defense responses like HR, lignin deposition and defense related enzyme phenylalanine ammonia-lyase (PAL, EC 4.3.1.5) were enhanced by NO donor treatments. NO may also participate in the onset of systemic acquired resistance (SAR) (Arasimowicz and Floryszak-Wieczorek, 2007). In tobacco exogenous NO induces the accumulation of salicylic acid (SA)-playing a fundamental role in SAR. Activation of pathogenesis related protein (PR-1), obtained via NO, occurs with the participation of SA, since as it was shown in transgenic plants unable to accumulate SA $(\mathrm{NabG})$, a similar effect was not observed (Durner et al., 1998). Moreover, disease spots caused by TMV on leaves pretreated with NO were considerably more reduced in comparison to those on transgenic ones. The application of inhibitors specific for animal NOS or NO scavengers reduced SAR (Song and Goodman, 2001). Thus, these results suggest an important role of $\mathrm{NO}$ in the induction of a distal signalling network leading to enhance SAR in tobacco (Arasimowicz and Floryszak-Wieczorek, 2007). NO also plays a key role in the formation of Blumeria graminis f.sp. hordei appressoria, since during infection, this pathogen depends on appressorium formation to penetrate the host (Prats et al., 2008). However, the downstream effects of NO generation in regulating appressorial development are unknown.

A role for $\mathrm{NO}$ in the induction of apoptosis in plant species (Magalhães et al., 1999) and during pathogen-induced programmed cell death (PCD) in Arabidopsis has been proposed (Neill et al., 2003), and it appears that the induction of PCD is determined by the interaction between $\mathrm{NO}$ and the ROS $\mathrm{O}_{2} *$ and $\mathrm{H}_{2} \mathrm{O}_{2}$ (Delledonne et al., 2001). In plant mitochondria, NO inhibits the cytochrome oxidase activity and the concomitant ATP synthesis, and altered mitochondrial activity stimulates PCD in plant cells (Yamasaki et al., 2001). It seems that the NO-induced PCD occurs by inhibition of respiration and the release of mitochondrial cytochrome c (Del Río et al., 2004).

Metacaspases are proteins likely involved in regulation of PCD processes (Uren et al., 2000). Thus, Belenghi 
et al. (2007) investigated the possible role of $\mathrm{NO}$ as a regulator of metacaspase activity in plants through $\mathrm{S}$ nitrosylation and observed that NO regulated the proteolytic activity of the Arabidopsis thaliana type-II metacaspase AtMC9 and that NO blocked autoprocessing and activation of the AtMC9 zymogen through S-nitrosylation of the catalytic cysteine residue.

\section{Interaction between $\mathrm{NO}$ and plant hormones}

There are many processes in which hormones and phytochrome interact or act separately to give the same response. NO also triggers several of these responses. These overlapping roles raise the question of whether light and hormones share common components in signal transduction pathways to elicit the same response and whether NO plays a role in this signalling cascade (Lamattina et al., 2003).

According to Kolbert et al. (2008), NO mediates auxin-induced adventitious and lateral root formation. The production of NO is associated with the NR enzyme during indole-3-butyric acid (IBA)-induced lateral root development in Arabidopsis thaliana. It was demonstrated that IBA was able to induce NO generation in wild-type plants, but failed to induce NO in the NR-deficient mutant.

NO may influence ethylene biosynthesis, e.g. in the maturation and senescence of plant tissue (Arasimowicz and Floryszak-Wieczorek, 2007). The application of exogenous NO to plants modulates the generation of ethylene (Zhu and Zhou, 2007). It is suggested that both gases act antagonistically. A recent report showed that NO directly acts by down-regulating ethylene synthesis through S-nitrosylation of methionine adenosyltransferase (MAT1) in Arabidopsis plants. The attachment of NO leads to the inhibition of MAT1 activity and results in the reduction of the pool of ethylene precursor Sadenosylmethionine (SAM) (Lindermayr et al., 2006).

As a molecule with important functions in plants, NO shares many signalling components with ABA, particularly those of $G$ protein-coupled signalling cascades, which include cGMP, $\mathrm{Ca}^{2+}$, cADPR, and $\mathrm{G}$ proteins (Wang et al., 2001). These imply cross-talk between NO and ABA (Xing et al., 2004). Some evidence was found to support this suggestion. Garcia-Mata and Lamattina (2001) showed that NO could induce stomatal closure in Vicia fava epidermal strips, and $\mathrm{NO}$ was indicated to be a component of ABA signalling pathways in ABAinduced stomatal closure.

Cytokinins (CKs) can stimulate photomorphogenic responses, mainly those related with the deetiolation process and pigment synthesis (Thomas et al., 1997). In dark-grown seedlings, exogenous application of CKs inhibits hypocotyl elongation in a manner similar to light treatment (Su and Howell, 1995). Likewise, NO reduced hypocotyl elongation in Arabidopsis and lettuce (Lactuca sativa L.) seedlings grown in the dark (Beligni and Lamattina, 2000). However, Romanov et al. (2008) reported that NO has no direct role in eliciting the primary CK response in plants.
Germination of the photoblastic lettuce seeds cv. Grand Rapids is a phytochrome-dependent process above $26^{\circ} \mathrm{C}$, and it was demonstrated that NO donors are able to promote germination in the dark to the same extent as both a GA treatment or a 5-min pulse of white light. However, seeds were also able to germinate in the light, in the presence of the NO scavenger 2-(4-carboxy2-phenyl)-4,4,5,5,-tetramethylimidazoline-1-oxyl-3-oxide (cPTIO), suggesting that light and NO can stimulate germination in different ways (Beligni and Lamattina, 2000). Whether GA and NO act in promoting germination through the same or different pathways remains to be determined (Lamattina et al., 2003).

\section{NO regulates gene expression}

As with ROS, NO also modulates the expression of genes when added to plant cells (Hancock et al., 2002). For example, NO increases the expression of defenserelated genes such as pathogenesis related protein $(P R$. 1), phenylalanine ammonia-lyase $(P A L)$ and glutathione S-transferase (GST) following pathogen challenge of soybean and tobacco (Delledonne et al., 1998; Durner et al., 1998). Furthermore, NO can also induce gene expression of several peroxidases, ferritin, and key enzymes of jasmonic acid biosynthesis (Del Río et al., 2004). In $A$. thaliana, NO can activate expression of GST, chalcone synthase $(C H S)$, glutathione peroxidase $(G P X)$, and alternative oxidase $(A O X 1 a)$ genes, and inhibit gene expression of thylacoidal ascorbate peroxidase $(t A P X)$ (Huang et al., 2002; Mackerness et al., 2001; Murgia et al., 2004).

The Arabidopsis ABA-dependent SnRK2 kinase, SRK2C/SnRK2.8, improves plant drought tolerance, probably by promoting the up-regulation of stress-responsive genes expression, including $D R E B 1 A / C B F 3$ encoding a transcription factor that broadly regulates stress-responsible genes (Umezawa et al., 2004). In addition, SnRK2 kinases can also phosphorylate and, in this way, activate transcription activators AREB1 and TRAB1 in Arabidopsis and rice, respectively (Kobayashi et al., 2005; Furihata et al., 2006). Thus, Courtois et al. (2008) suggested that SnRK2 protein kinases are involved in the regulation of expression of ABA-responsive genes; besides, plant cells challenged by osmotic stress might use $\mathrm{NO}$ as an early signalling compound acting upstream of SnRK2-induced pathways.

Wilkinson and Crawford (1993) observed low NR activity in the Arabidopsis G'4-3 NR-deficient mutant, which is deleted for the Nia2 gene and carries a point mutation in the Nia1 gene; both genes code for NR apoenzyme in Arabidopsis. In addition, Desikan et al. (2002) reported that neither nitrite nor $\mathrm{ABA}$ were able to provoke $\mathrm{NO}$ synthesis and stomatal closure in this mutant. Guo et al. (2003b) observed lower light-induced stomatal opening and higher resistance to drought in Arabidopsis due to a mutation of the nitrate transporter Chl1 gene, which is highly expressed in guard cells. Also, Meyer et al. (2005) suggested that AtNOS1 could be involved not only in NO production, but also in stomatal closure in response to ABA, at least in Arabidopsis guard cells. 
Courtois et al. (2008) stated that it is reasonable to speculate that $\mathrm{NO} / \mathrm{Ca}^{2+}$ pathways, as well as the combined action of $\mathrm{NO}$ and $\mathrm{Ca}^{2+}$, might modulate the transcriptional regulation of specific set of genes involved, for instance, in disease resistance or developmental processes.

\section{Concluding Remarks}

Proteomic and transcriptomic strategies have led to the identification of numerous NO target genes and proteins. However, the molecular mechanisms underlying its effects remain poorly understood. Furthermore, proteins undergoing Tyr nitration and novel proteins nitrosylated need to be in vivo-identified. It has not yet been possible to identify a plant enzyme displaying a NOS-like activity, as well as the source of NO in particular physiological context. Thus, biochemical purification of the enzyme displaying NOS-like activity is a main priority. Besides, the molecular-level elucidation of the pathways by which NO is synthesized from LArg and polyamines is required.

The mechanisms underlying $\mathrm{NO}$ effects in vivo are still rudimentary. In addition, future works will have to clarify the tight interplays among $\mathrm{NO}, \mathrm{Ca}^{2+}$, cADPR, and protein kinases. It remains to be seen whether the level of cADPR changes in response to NO-dependent processes. In addition, it is necessary to understand how interplays between $\mathrm{NO}$ and $\mathrm{Ca}^{2+}$ guide the cell toward a specific response. Besides, the plant NO-sensitive soluble guanylate cyclase (sGC)-like enzyme is unknown, and the putative involvement of NtOSAK and MAPKs in NO-induced $\left[\mathrm{Ca}^{2+}\right]_{\text {cyt }}$ rises needs to be established.

Although the requirement of phosphorylation-dependent events in the mediation of NO-induced $\mathrm{Ca}^{2+}$ mobilization has been reported, plant cGMP-dependent protein kinases (PKGs) have not yet been identified. Besides, although it seems plausible that interplays of $\mathrm{NO}$ and $\mathrm{Ca}^{2+}$ might be implicated in cell death, experiments designed to delineate the cross-talk between $\mathrm{Ca}^{2+}, \mathrm{NO}$, and $\mathrm{H}_{2} \mathrm{O}_{2}$ in further detail will clarify the understanding of the mechanisms underlying such process.

\section{References}

Ali, R.; Ma, W.; Lemtiri-Chlieh, F.; Tsaltas, D.; Leng, Q.; Von Bodman, S.; Berkowitz, G.A. 2007. Death don't have no mercy and neither does calcium: Arabidopsis CYCLIC NUCLEOTIDE GATED CHANNEL2 and innate immunity. The Plant Cell 19: 1081-1095.

Alonso, J.M.; Stepanova, A.N.; Leisse, T.J.; Kim, C.J.; Chen, H.; Shinn, P.; Stevenson, D.K.; Zimmerman, J.; Barajas, P.; Cheuk, R.; Gadrinab, C.; Heller, C.; Jeske, A.; Koesema, E.; Meyers, C.C.; Parker, H.; Prednis, L.; Ansari, Y.; Choy, N.; Deen, H.; Geralt, M.; Hazari, N.; Hom, E.; Karnes, M.; Mulholland, C.; Ndubaku, R.; Schmidt, I.; Guzman, P.; Aguilar-Henonin, L.; Schmid, M.; Weigel, D.; Carter, D.E.; Marchand, T.; Risseeuw, E.; Brogden, D.; Zeko, A.; Crosby, W.L.; Berry, C.C.; Ecker, J.R. 2003. Genone-wide insertional mutagenesis of Arabidopsis thaliana. Science 301: 653-657.
Arasimowicz, M.; Floryszak-Wieczorek, J. 2007. Nitric oxide as a bioactive signalling molecule in plant stress responses. Plant Science 172: 876-887.

Belenghi, B.; Romero-Puertas, M.C.; Vercammen, D.; Brackenier, A.; Inzé, D.; Delledonne, M.; Van Breusegem, F. 2007. Metacaspase activity of Arabidopsis thaliana is regulated by Snitrosylation of a critical cysteine residue. Journal of Biological Chemistry 282: 1352-1358.

Beligni, M.V.; Lamattina, L. 1999a. Is nitric oxide toxic or protective? Trends in Plant Science 4: 299-300.

Beligni, M.V.; Lamattina, L. 1999b. Nitric oxide counteracts cytotoxic processes mediated by reactive oxygen species in plant tissues. Planta 208: 337-344.

Beligni, M.V.; Lamattina, L. 1999c. Nitric oxide protects against cellular damage produced by methylviologen herbicides in potato plants. Nitric Oxide: Biology and Chemistry 3: 199 208.

Beligni, M.V.; Lamattina, L. 2000. Nitric oxide stimulates seed germination and de-etiolation, and inhibits hypocotyl elongation, three light-inducible responses in plants. Planta 210: 215-221.

Besson-Bard, A.; Courtois, A.; Dahan, J.; Dobrowolska, G.; Jeandroz, S.; Pugin, A.; Wendehenne, D. 2008a. Nitric oxide in plants: production and cross-talk with $\mathrm{Ca}^{2+}$ signaling. Molecular Plant 1: 218-228.

Besson-Bard, A.; Pugin, A.; Wendehenne, D. 2008b. New insights into nitric oxide signaling in plants. Annual Review of Plant Biology 59: 21-39.

Bethke, P.C.; Badger, M.R.; Jones, R.L. 2004. Apoplastic synthesis of nitric oxide by plant tissues. The Plant Cell 16: 332-341.

Bethke, P.C.; Libourel, I.G.L.; Jones, R.L. 2006. Nitric oxide reduces seed dormancy in Arabidopsis. Journal of Experimental Botany 57: 517-526.

Butt, Y.K.-C.; Lum, J.H.-K.; Lo, S.C.-L. 2003. Proteomic identification of plant proteins probed by mammalian nitric oxide synthase antibodies. Planta 216: 762-771.

Chandok, M.R.; Ytterberg, A.J.; Van Wijk, K.J.; Klessig, D.F. 2003. The pathogen-inducible nitric oxide synthase (iNOS) in plants is a variant of the $\mathrm{P}$ protein of the glycine decarboxylase complex. Cell 113: 469-482.

Cooney, R.V.; Harwood, P.J.; Custer, L.J.; Franke, A.A. 1994. Light-mediated conversion of nitrogen dioxide to nitric oxide by carotenoids. Environmental Health Perspectives 102: 460462.

Courtois, C.; Besson, A.; Dahan, J.; Bourque, S.; Dobrowolska, G.; Pugin, A.; Wendehenne, D. 2008. Nitric oxide signalling in plants: interplays with $\mathrm{Ca}^{2+}$ and protein kinases. Journal of Experimental Botany 59: 155-163.

Crawford, N.M. 2006. Mechanisms for nitric oxide synthesis in plants. Journal of Experimental Botany 57: 471-478.

Crawford, N.M.; Galli, M.; Tischner, R.; Heimer, Y.M.; Okamoto, M.; Mack, A. 2006. Response to Zemojtel et al.: plant nitric oxide synthase: back to square one. Trends in Plant Science 11: 526-527.

Del Río, L.A.; Corpas, F.J.; Barroso, J.B. 2004. Nitric oxide and nitric oxide synthase activity in plants. Phytochemistry 65: 783-792.

Delledonne, M.; Xia, Y.; Dixon, R.A.; Lamb, C. 1998. Nitric oxide functions as a signal in plant disease resistance. Nature 394: 585588.

Delledonne, M.; Zeier, J.; Marocco, A.; Lamb, C. 2001. Signal interactions between nitric oxide and reactive oxygen intermediates in the plant hypersensitive disease-resistance response. Proceedings of the National Academy of Sciences of the USA 98: 13454-13459.

Desikan, R.; Griffiths, R.; Hancock, J.; Neill, S. 2002. A new role for an old enzyme: nitrate reductase-mediated nitric oxide generation is required for abscisic acid-induced stomatal closure in Arabidopsis thaliana. Proceedings of the National Academy of Sciences of the USA 99: 16314-16318. 
Durner, J.; Klessig, D.F. 1999. Nitric oxide as a signal in plants. Current Opinion in Plant Biology 2: 369-374.

Durner, J.; Wendehenne, D.; Klessig, D.F. 1998. Defense gene induction in tobacco by nitric oxide, cyclic GMP, and cyclic ADP-ribose. Proceedings of the National Academy of Sciences of the USA 95: 10328-10333.

Ferrer, M.A.; Ros Barcelo, A. 1999. Differential effects of nitric oxide on peroxidase and $\mathrm{H}_{2} \mathrm{O}_{2}$ production by the xylem of Zinnia elegans. Plant, Cell and Environment 22: 891-897.

Fliegert, R.; Gasser, A.; Guse, A.H. 2007. Regulation of calcium signalling by adenine-based second messengers. Biochemical Society Transactions 35: 109-114.

Furihata, T.; Maruyama, K.; Fujita, Y.; Umezawa, T.; Yoshida, R.; Shinozaki, K.; Yamaguchi-Shinozaki, K. 2006. Abscisic acid-dependent multisite phosphorylation regulates the activity of a transcription activator AREB1. Proceedings of the National Academy of Sciences of the USA 103: 19881993.

Garcia-Mata, C.; Lamattina, L. 2003. Abscisic acid, nitric oxide and stomatal closure - is nitrate reductase one of the missing links? Trends in Plant Science 8: 20-26.

Garcia-Mata, C.; Lamattina, L. 2001. Nitric oxide induces stomatal closure and enhances the adaptive plant responses against drought stress. Plant Physiology 126: 1196-1204.

Giba, Z.; Grubisic, D.; Todorovic, S.; Sajc, L.; Stojakovic, D.; Konjevic, T. 1998. Effect of nitric oxide-releasing compounds on phytochrome-controlled germination of Empress tree seeds. Plant Growth Regulation 26: 175-181.

Godber, B.L.J.; Doel, J.J.; Sapkota, G.P.; Blake, D.R.; Stevens, C.R.; Eisenthal, R.; Harrison, R. 2000. Reduction of nitrite to nitric oxide catalyzed by xanthine oxidoreductase. Journal of Biological Chemistry 275: 7757-7763.

Grün, S.; Lindermayr, C.; Sell, S.; Durner, J. 2006. Nitric oxide and gene regulation in plants. Journal of Experimental Botany 57: 507-516.

Guo, F.Q.; Okamoto, M.; Crawford, N.M. 2003a. Identification of a plant nitric oxide synthase gene involved in hormonal signaling. Science 302: 100-103.

Guo, F.Q.; Young, J.; Crawford, N.M. 2003b. The nitrate transporter AtNRT1.1 (CHL1) functions in stomatal opening and contributes to drought susceptibility in Arabidopsis. The Plant Cell 15: 107-117.

Hancock, J.T.; Desikan, R.; Clarke, A.; Hurst, R.D.; Neill, S.J. 2002. Cell signalling following plant/pathogen interactions involves the generation of reactive oxygen and reactive nitrogen species. Plant Physiology and Biochemistry 40: 611617.

Herouart, D.; Baudouin, E.; Frendo, P.; Harrison, J.; Santos, R.; Jamet, A.; Van De Sype, G.; Touati, D.; Puppo, A. 2002. Reactive oxygen species, nitric oxide and glutathione: a key role in the establishment of the legume-Rhizobium symbiosis? Plant Physiology and Biochemistry 40: 619-624.

Hess, D.T.; Matsumoto, A.; Kim, S.O.; Marshall, H.E.; Stamler, J.S. 2005. Protein S-nitrosylation: purview and parameters. Nature Reviews Molecular Cell Biology 6: 150-166.

Hsu, Y.T.; Kao, C.H. 2004. Cadmium toxicity is reduced by nitric oxide in rice leaves. Plant Growth Regulation 42: 227238.

Huang, X.; Von Rad, U.; Durner, J. 2002. Nitric oxide induces transcriptional activation of the nitric oxide-tolerant alternative oxidase in Arabidopsis suspension cells. Planta 215: 914-923.

Hung, K.T.; Chang, C.J.; Kao, C.H. 2002. Paraquat toxicity is reduced by nitric oxide in rice leaves. Journal of Plant Physiology 159: 159-166.

Klepper, L.A. 1975. Inhibition of nitrite reduction by photosynthetic inhibitors. Weed Science 23: 188-190.

Klepper, L.A. 1979. Nitric oxide (NO) and nitrogen dioxide $\left(\mathrm{NO}_{2}\right)$ emissions from herbicide-treated soybean plants. Atmospheric Environment 13: 537-542.
Kobayashi, Y.; Murata, M.; Minami, H.; Yamamoto, S.; Kagaya, Y.; Hobo, T.; Yamamoto, A.; Hattori, T. 2005. Abscisic acid-activated SNRK2 protein kinases function in the generegulation pathway of $\mathrm{ABA}$ signal transduction by phosphorylating $\mathrm{ABA}$ response element-binding factors. The Plant Journal 44: 939-949.

Kolbert, Z.; Bartha, B.; Erder, L. 2008. Exogenous auxin-induced NO synthesis is nitrate reductase-associated in Arabidopsis thaliana root primordia. Journal of Plant Physiology 165: 967975.

Kopyra, M.; Gwózdz, F.A. 2003. Nitric oxide stimulates seed germination and counteracts the inhibitory effect of heavy metals and salinity on root growth of Lupinus luteus. Plant Physiology and Biochemistry 41: 1011-1017.

Lamattina, L.; Garcia-Mata, C.; Graziano, M.; Pagnussat, G. 2003. Nitric oxide: the versatility of an extensive signal molecule. Annual Review of Plant Biology 54: 109-136.

Lamotte, O.; Courtois, C.; Dobrowolska, G.; Besson, A.; Pugin, A.; Wendehenne, D. 2006. Mechanism of nitric-oxide-induced increase of free cytosolic $\mathrm{Ca}^{2+}$ concentration in Nicotiana plumbaginifolia cells. Free Radical Biology and Medicine 40: 1369-1376.

Lamotte, O.; Gould, K.; Lecourieux, D.; Sequeira-Legrand, A.; Lebrun-Garcia, A.; Durner, J.; Pugin, A.; Wendehenne, D. 2004 Analysis if nitric oxide signalling functions in tobacco cells challenged by the elicitor cryptogein. Plant Physiology 135: 516-530.

Laspina, N.V.; Groppa, M.D.; Tomaro, M.L.; Benavides, M.P. 2005. Nitric oxide protects sunflower leaves against Cd-induced oxidative stress. Plant Science 169: 323-330.

Leshem, Y.Y. 1996. Nitric oxide in biological systems. Plant Growth Regulation 18: 155-159.

Leshem, Y.Y. 2000. Nitric Oxide in Plants. Occurrence, Function and Use. 1ed. Kluwer Academic, Dordrecht, The Netherlands.

Lindermayr, C.; Saalbach, G.; Bahnweg, G.; Durner, J. 2006. Differential inhibition of Arabidopsis methionine adenosyltransferases by protein S-nitrosylation. Journal of Biological Chemistry 281: 4285-4291.

Mackerness, S.A.H.; John, C.F.; Jordan, B.; Thomas, B. 2001. Early signalling components in ultraviolet-B responses: distinct roles for different reactive oxygen species and nitric oxide. FEBS Letters 489: 237-242.

Magalhães, J.R.; Pedroso, M.C.; Durzan, D.J. 1999. Nitric oxide, apoptosis and plant stresses. Physiology and Molecular Biology of Plants 5: 115-125.

Manjunatha, G.; Raj, S.N.; Shetty, N.P.; Shetty, H.S. 2008. Nitric oxide donor seed priming enhances defense responses and induces resistance against pearl millet downy mildew disease. Pesticide Biochemistry and Physiology 91: 1-11.

Meyer, C.; Lea, U.S.; Provan, F.; Kaiser, W.M.; Lillo, C. 2005. Is nitrate reductase a major player in the plant NO (nitric oxide) game? Photosynthesis Research 83: 181-189.

Morot-Gaudry-Talarmain, Y.; Rockel, P.; Moureaux, T.; Quilleré, I.; Leydecker, M.T.; Kaiser, W.M.; Morot-Gaudry, J.F. 2002. Nitrite accumulation and nitric oxide emission in relation to cellular signalling in nitrite reductase antisense tobacco. Planta 215: 708-715.

Murgia, I.; Tarantino, D.; Vannini, C.; Bracale, M.; Carravieri, S.; Soave, C. 2004. Arabidopsis thaliana plants overexpressing thylacoidal ascorbate peroxidase show increased resistance to Paraquat-induced photo-oxidative stress to nitric oxide-induced cell death. The Plant Journal 38: 940-953.

Neill, S.J.; Desikan, R.; Clarke, A.; Hancock, J.T. 2002. Nitric oxide is a novel component of abscisic acid signalling in stomatal guard cells. Plant Physiology 128: 13-16.

Neill, S.J.; Desikan, R.; Hancock, J.T. 2003. Nitric oxide signalling in plants. New Phytologist 159: 11-35.

Orozco-Cárdenas, M.; Ryan, C.A. 2002. Nitric oxide negatively modulates wound signalling in tomato plants. Plant Physiology 130: 487-493. 
Pagnussat, G.C.; Simontacchi, M.; Puntarulo, S.; Lamattina, L. 2002. Nitric oxide is required for root organogenesis. Plant Physiology 129: 954-956.

Prats, E.; Carver, T.L.W.; Mur, L.A.J. 2008. Pathogen-derived nitric oxide influences formation of the appressorium infection structure in the phytopathogenic fungus Blumeria graminis. Research in Microbiology 159: 476-480.

Ribeiro Jr., E.A.; Cunha, F.Q.; Tamashiro, W.M.; Martins, I.S. 1999. Growth phase-dependent subcellular localization of nitric oxide synthase in maize cells. FEBS Letters 445: 283-286.

Romanov, G.A.; Lomin, S.N.; Rakova, N.Y.; Heyl, A.; Schmülling, T. 2008. Does NO play a role in cytokinin signal transduction? FEBS Letters 582: 874-880.

Saito, S.; Yamamoto-Katou, A.; Yoshioka, H.; Doke, N.; Kawakita, K. 2006. Peroxynitrite generation and tyrosine nitration in defense responses in tobacco BY-2 cells. Plant and Cell Physiology 47: 689-697.

Song, F.; Goodman, R.M. 2001. Activity of nitric oxide is dependent on, but is partially required for function of salicylic acid in the signalling pathway in tobacco systemic acquired resistance. Molecular Plant-Microbe Interactions 12: 1458-1462.

Stamler, J.S.; Lamas, S.; Fang, F.C. 2001. Nitrosylation: the prototypic redox-based signalling mechanism. Cell 6: 675-683.

Stöhr, C.; Stremlau, S. 2006. Formation and possible roles of nitric oxide in plant roots. Journal of Experimental Botany 57: 463470.

Stöhr, C.; Strube, F.; Marx, G.; Ulrich, W.R.; Rockel, P. 2001. A plasma membrane-bound enzyme of tobacco roots catalyses the formation of nitric oxide from nitrite. Planta 212: 835-841.

Su, W.; Howell, S.H. 1995. The effects of cytokinin and light on hypocotyl elongation in Arabidopsis seedlings are independent and additive. Plant Physiology 108: 1423-1430.

Sun, B.; Jing, Y.; Chen, K.; Song, L.; Chen, F.; Zhang, L. 2007. Protective effect of nitric oxide on iron deficiency-induced oxidative stress in maize (Zea mays). Journal of Plant Physiology 164: 536-543.

Thérond, P.; Bonnefont-Rousselot, D.; Davit-Spraul, A.; Conti, M.; Legrand, A. 2000. Biomarkers of oxidative stress: an analytical approach. Current Opinion in Clinical Nutrition and Metabolic Care 3: 373-384.

Thomas, T.H.; Hare, P.D.; Van Staden, J. 1997. Phytochrome and cytokinin responses. Plant Growth Regulation 23: 105-122.

Tun, N.N.; Santa-Catarina, C.; Begum, T.; Silveira, V.; Handro, W.; Floh, E.I.S.; Scherer, G.F.E. 2006. Polyamines induced rapid biosynthesis of nitric oxide (NO) in Arabidopsis thaliana seedlings. Plant and Cell Physiology 47: 346-354.

Umezawa, T.; Yoshida, R.; Maruyama, K.; Yamaguchi-Shinozaki, K.; Shinozaki, K. 2004. SRK2C, a SNF1-related protein kinase 2 , improves drought tolerance by controlling stress-responsive gene expression in Arabidopsis thaliana. Proceedings of the National Academy of Sciences of the USA 101: 17306-17311.

Uren, A.G.; O’Rourke, K.; Aravind, L.; Pisabarro, M.T.; Seshagiri, S.; Koonin, E.V.; Dixit, V.M. 2000. Identification of paracaspases and metacaspases: two ancient families of caspase-like proteins, one of which plays a key role in MALT lymphoma. Molecular Cell 6: 961-967.

Valderrama, R.; Corpas, F.J.; Carreras, A.; Fernandez-Ocana, A.; Chaki, M.; Luque, F.; Gómez-Rodríguez, M.; Colmenero-Varea, P.; Del Río, L.; Barroso, J. 2007. Nitrosative stress in plants. FEBS Letters 581: 453-461.

Van Breusegem, F.; Vranová, E.; Dat, J.F.; Inze, D. 2001. The role of active oxygen species in plant signal transduction. Plant Science 161: 405-414.
Van Camp, W.; Van Montagu, M.; Inze, D. 1998. $\mathrm{H}_{2} \mathrm{O}_{2}$ and NO: redox signals in disease resistance. Trends in Plant Science 3: 330-334.

Vandelle, E.; Poinssot, B.; Wendehenne, D.; Bentéjac, M.; Pugin, A. 2006. Integrated signaling network involving calcium, nitric oxide, and active oxygen species but not mitogen-activated protein kinases in BcPG1-elicited grapevine defenses. Molecular Plant-Microbe Interactions 19: 429-440.

Wang, X.Q.; Ullah, H.; Jones, A.M.; Assmann, S.M. 2001. G proteins regulation of ion channels and abscisic acid signalling in Arabidopsis guard cells. Science 292: 2070-2072.

Wilkinson, J.Q.; Crawford, N.M. 1993. Identification and characterization of a chlorate resistant mutant of Arabidopsis thaliana with mutations in both nitrate reductase structural genes NIA1 and NIA2. Molecular and General Genetics 239: 289-297.

Wink, D.A.; Hanbauer, I.; Krishna, M.C.; De Graff, W.; Gamson, J.; Mitchel, J.B. 1993. Nitric oxide protects against cellular damage and cytotoxicity form reactive oxygen species. Proceedings of the National Academy of Sciences of the USA 90: 9813-9817.

Wink, D.A.; Mitchell, J.B. 1998. Chemical biology of nitric oxide: insights into regulatory, cytotoxic, and cytoprotective mechanisms of nitric oxide. Free Radical Biology and Medicine 25: 434-456.

Wojtaszek, P. 2000. Nitric oxide in plants. To NO or not to NO. Phytochemistry 54: 1-4.

Xing, H.; Tan, L.; An, L.; Zhao, Z.; Wang, S.; Zhang, C. 2004. Evidence for the involvement of nitric oxide and reactive oxygen species in osmotic stress tolerance of wheat seedlings: inverse correlation between leaf abscisic acid accumulation and leaf water loss. Plant Growth Regulation 42: 61-68.

Yamasaki, H. 2005. The NO world for plants: achieving balance in an open system. Plant, Cell and Environment 28: 78-84.

Yamasaki, H.; Cohen, M.F. 2006. NO signal at the crossroads: polyamine-induced nitric oxide synthesis in plants? Trends in Plant Science 11: 522-524.

Yamasaki, H.; Sakihama, Y.; Takahashi, S. 1999. An alternative pathway for nitric oxide production in plants: new features of an old enzyme. Trends in Plant Science 4: 128-129.

Yamasaki, H.; Shimoji, H.; Ohshiro, Y.; Sakihama, Y. 2001. Inhibitory effects of nitric oxide on oxidative phosphorylation in plant mitochondria. Nitric Oxide: Biology and Chemistry 5: 261-270.

Zanardo, D.I.L.; Zanardo, F.M.L.; Ferrarese, M.L.L.; Magalhaes, J.R.; Ferrarese-Filho, O. 2005. Nitric oxide affecting seed germination and peroxidase activity in canola (Brassica napus L.). Physiology and Molecular Biology of Plants 11: 81-86.

Zhao, L.; Zhang, F.; Guo, J.; Yang, Y.; Li, B.; Zhang, L. 2004. Nitric oxide functions as a signal in salt resistance in the calluses from two ecotypes of reed. Plant Physiology 134: 848-857.

Zhao, M.; Zhao, X.; Wu, Y.; Zhang, L. 2007. Enhanced sensitivity to oxidative stress in an Arabidopsis nitric oxide synthase mutant. Journal of Plant Physiology 164: 737-745.

Zhu, S.H.; Zhou, J. 2007. Effect of nitric oxide on ethylene production in strawberry fruit during storage. Food Chemistry 100: 1517-1522.

Received October 13, 2008

Accepted October 05, 2009 